\title{
Virtual Identity Transformations
}

\author{
Mary Stokrocki* \\ Arizona State University, USA
}

Submission: February 03, 2020; Published: February 20, 2020

*Corresponding author: Mary Stokrocki, Professor, Arizona State University, School of Art, PO Box 871505, Tempe, Arizona, USA

Abstract

As I travel through different communities on virtual worlds and in reality, I explain my transforming avatar identity. My identity became more playful and creative when one of my graduate students invited me to the virtual world of Second Life. My most notable transmutation however is The Lizard of ARS because she can change her color to blend into the landscape, can give birth without males, and she can regenerate her tail. This regeneration is her most remarkable feature because every time she loses it, she has to invent a new one. As the Lizard of ARS, she wanders around looking for a new tale and inviting colleagues, teachers, and students to help her invent a new one. Her parody identity unfolds, and she transforms in real life as she visits students in the schools to ask them to reinvent ART.

Keywords: Identity; Virtual world; Avatar; Fool; Transforms; Appropriation

\section{Introduction}

\section{Identity}

Identity is a set of unique characteristics that denote a person. A person's identity however is multifaceted and transforming; parts are hidden, determined by culture [and community], and are never final [1]. Jagodzinski [2] reported that media immersion offers brief transcendence from these youths' preoccupation with their own life problems, and ways of role-playing solutions. In our postmodern world, a person, young and old, can have multiple identities in the digital universe, more specifically virtual worlds called avatars in online communities.

\section{Virtual worlds}

Virtual worlds are one of the major sites of informal multiliteracy education. "With over 60 online virtual worlds, 400 universities offering courses, and 50\% from different countries, these sites offer tremendous opportunities for artistic teaching and learning [3]. Second Life, still one of the most popular, have helped me grow by increasing my literacy skills to include multi ways of communicating and teaching [3] and expanding my creativity and vision through avatars.

\section{Avatars}

Avatars are representations of people who participate in virtual worlds (Meadows, 2008). In her study of avatar identities, Liao [3] raised questions about the connections we make between representation and identity, what constitutes identity, and the ways in which identity and representation may both dovetail with and yet contradict each other. My avatars transform in different ways in different worlds.

\section{Transformations}

When one of my graduate students, Sandy Andrews [avatar Ozma), introduced me to the virtual world of Second Life, I was a cat, representing my beloved feline who just died. Ozma invited me to teach at her Floaters site on the virtual world of Second Life (Figure 1). Floaters is a safe place for disenfranchised people to share their artworks. The site still exists on Second Life with updated exhibitions from real life, The Millet House in Mesa Arizona. Our research shared the importance of empowering poor youths, mentoring them, and helping them develop personal learning environments [4]. My normal avatar on Second life was human. Marylou Goldrosen built her Art Ark school (Figure 2a) and started the Art Ark Warriors Group (Figure 2b). The kilim is a handmade, sumak rug made of silk, cotton, and wool from Diyarbakir, East Turkey that I purchased when working for the World Bank in Ankara in 1995 [5]. I use the carpet to teach art criticism, inviting students to look for treasures in the rug and on Second Life. On Halloween, my avatar each year turns into Spider Women, celebrating the Feast of Fools. She loves to spy, dance, and invite students to reinvent themselves (Figure 3a). This ghoul explores society's foolish antics [6]. She loves the mesh netting too (Figure 3b). 
The Women's Caucus, of which she is Co-President (201819), challenged her to transcend her identity. She chose a Fembot [robot-an inclusionary feminist, despite the pink]. See Figure 4. I had to compile my research and teaching on cyber worlds [7]. Andrea Karpati [8] reviewed my work as "richly illustrated and carefully designed for easy use, offers witty narratives on good art education practice in cyberspace and evidence-based reports on student development that make it a valuable resource for art teachers, trainers and researcher as well".

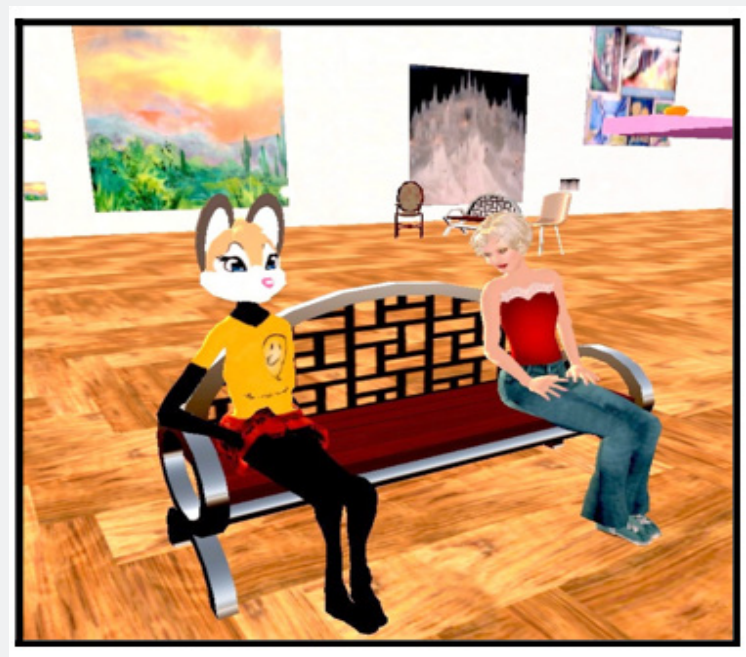

Figure 1: My Cat Avatar wears my Sponge Babe outfit and my uploaded painting of my local Superstitions Mountain and creatures turned into a children's book [far right] [13].

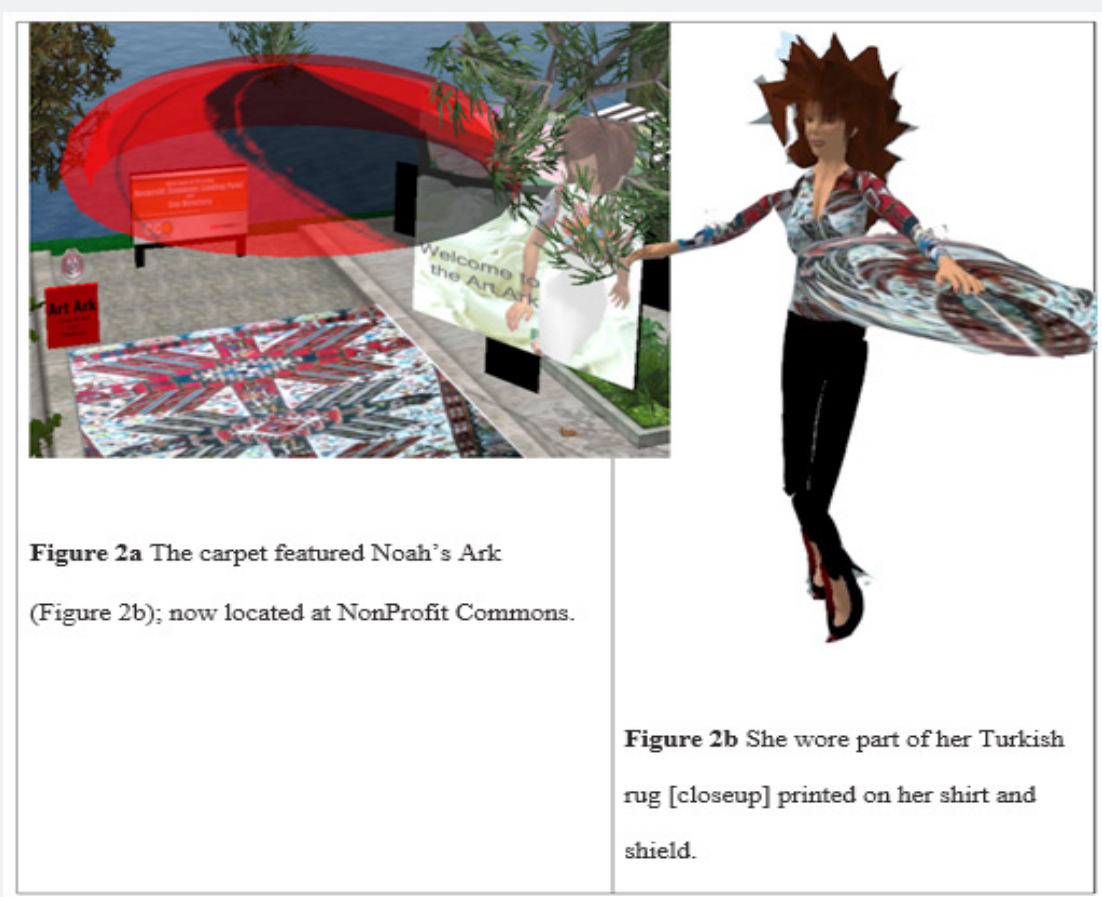

Figure 2:

2a: The carpet featured Noah's Ark (Figure 2b); now located at Non-Profit Commons.

$2 \mathrm{~b}$ : She wore part of her Turkish rug [closeup] printed on her shirt and shield.

When teaching local students on the Opensim, another virtual world site sponsored by Sandrine Han from the University of British Columbia, my identity transformed into Queen Bee (Figure
5) with her own hive. Locally, she is Lady Bug at my local Earth Bazaar, where she roams around asking attendants "What's bugging them?". 


\section{Current Trends in Fashion Technology \& Textile Engineering}

Figure 3:

3a: Spider Women emerges each Halloween for something to "ingest" via parody.

3b: She spins in new mesh netting Skirt.

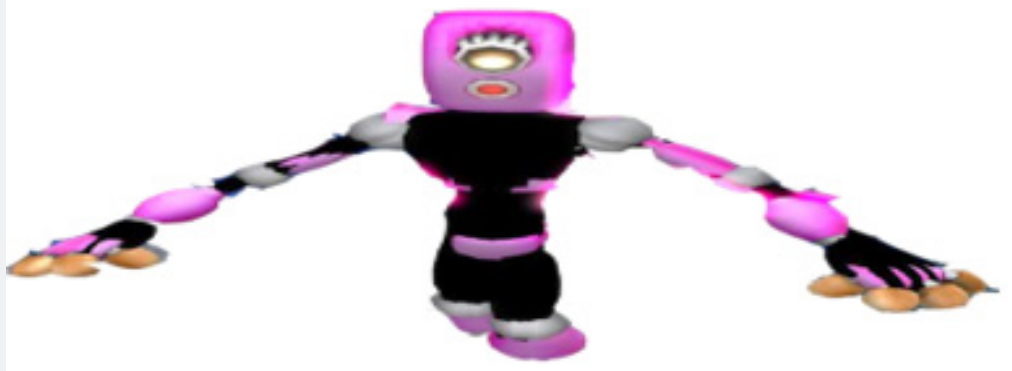

Figure 4: Women's Caucus Fembot on Second Life.

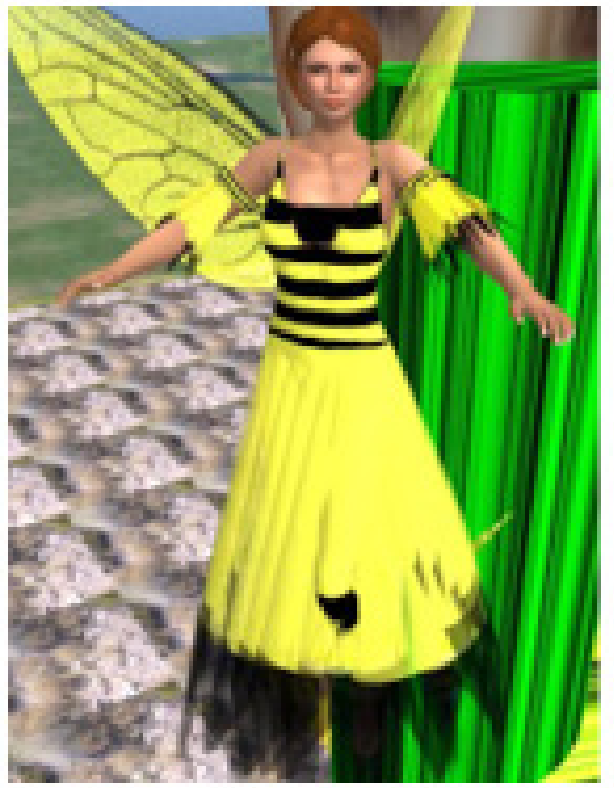

Figure 5: On the Opensim, my identity transformed into a Queen Bee. 
My most notable transmutation however is The Lizard of ARS/ ART, who can change her color to blend into the landscape, can give birth without males, and regenerate her tail (Figure 6a). She wanders around looking for a new tail/tale and inviting colleagues, teachers, and students to help her invent a new one, a new parody. Her identity transforms, a re-presentation of existing appropriated material [9] in different ways. When reviewing the appropriation history, Lethem [10] argues that recombining sound, visuals and text are plagiarisms that date back to Shakespeare et al. Because such image reuse is so easy and inexpensive with digital media. Downloading the mask and wearing a green jumpsuit, she visits students in the schools to asks them to reinvent ART (Figure 6b).

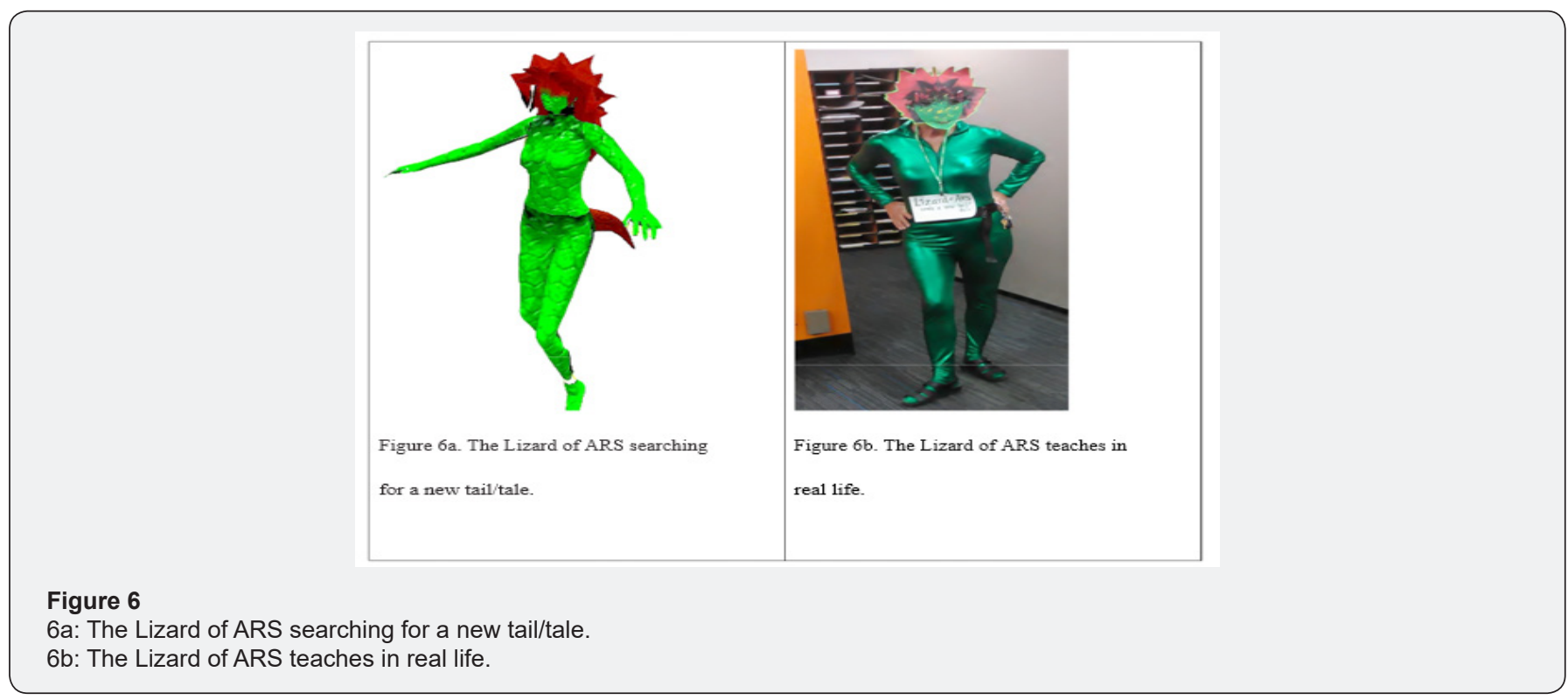

\section{Conclusion}

Virtual identity encompasses all these community relations, when reinventing ARS (Figure 7). This is the childish in me as revealed in Our Digital Selves: My Avatar is me [12-15]. environments, and new platforms [11]. Identity transforms faster

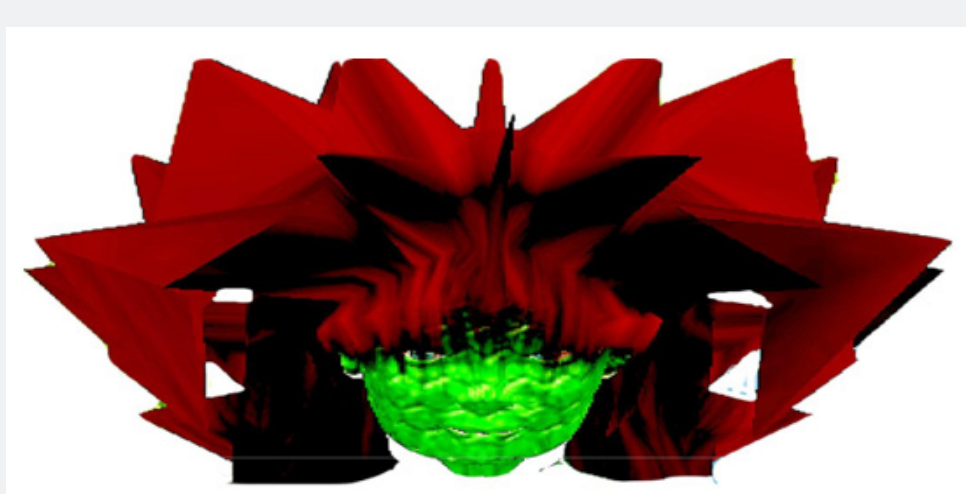

Figure 7: Don't get her mad because she will turn BURNING RED like a chameleon. Her gusto transforms and off she goes leaping around for more artful ideas to transplant.

\section{References}

1. Kroger Jane (1996) Identity in adolescence: The balance between self and other. (1 $1^{\text {st }}$ edn), Routledge, US, pp. 1-288.

2. (2004) Youth fantasies: The perverse landscape of the media. In: Jagodzinski J, ( $1^{\text {st }}$ edn), Palgrave Macmillan, US, pp. 1-281.

3. Liao C (2014) Avatar Art-Making as a Creative Exploration of Identity In Stokrocki M (2014) Exploration in Virtual Worlds: New Digital Multi-Media Literacy Investigations for Art Education. US, pp. 83-92.
4. Stokrocki M, Andrews S (2010) Empowering the Disenfranchised through Explorations in Second Life. In: Sweeny R (Ed.), Intersections and Interactions in 21st century art education: Art education in a digital visual culture. pp. 197-209.

5. Stokrocki M (1999) Looking for Lost Treasure: A Narrative Exploration of the Meanings of a Turkish Kilim. Visual Arts Research, 24(2): 61-66.

6. Stokrocki M (1997) The aesthetics of the foolish and the ghoulish: An exploratory study of Halloween antics and preferences. Cat's Cradle 2(2): 41-51. 
7. Stokrocki M (2015) Art education qualitative research in cyberworlds. In: Kathy Miraglia, Cathy Smilan (Eds.), Inquiry in Action: Paradigms, Methodologies and Perspectives in Art Education Research. pp. 204210

8. Karpati A (2014) International Journal of Education through Art. In: Intellect 1(2): 330-332.

9. Baum LF (1900) The Wonderful Wizard of Oz. In: George M Hill Company: Chicago (2018). Our Digital Selves: My Avatar is me [full feature film].

10. Lethem Jonathan (2007) The ecstasy of influence. A plagiarism, Harper's Magazine, pp. 1-11.
11. Sansar (2017) Sansar Will Open to All in First Half of 2017 with a New Approach to Virtual Worlds.

12. Richards A, Willis S (2018) Global Consciousness through the Arts: A Passport for Students and Teachers. (2 ${ }^{\text {nd }}$ edn), pp. 1-204.

13. Stokrocki M, Emily York (2009) In: TJ, Desert Surprise, EYE Exceptionals, 2851 Century Harbor, Middleton, WI. 53562.

14. Reston (2014) VA: National Art Education Association. In: Stokrocki M (Ed.), Exploration in Virtual Worlds: New Digital Multi-Media Literacy Investigations for Art Education.

15. Stokrocki M (2016) The Lizards of ARS: A Participatory Aesthetic Parody Play. International Journal of Arts Education 14(2): 39-51.

\begin{tabular}{|l|}
\hline $\begin{array}{c}\text { Your next submission with Juniper Publishers } \\
\text { will reach you the below assets }\end{array}$ \\
- Quality Editorial service \\
- Swift Peer Review \\
- Reprints availability \\
- E-prints Service \\
- Manuscript Podcast for convenient understanding \\
- Global attainment for your research \\
- Manuscript accessibility in different formats \\
( Pdf, E-pub, Full Text, Audio) \\
- Unceasing customer service \\
Track the below URL for one-step submission \\
https://juniperpublishers.com/online-submission.php \\
\hline
\end{tabular}

